\title{
GAMMARUS FOSSARUM KOCH, 1835: REDESCRIPTION BASED ON NEOTYPE MATERIAL AND NOTES ON ITS LOCAL VARIATION (CRUSTACEA, AMPHIPODA)
}

\author{
by \\ ANNEMARIE GOEDMAKERS \\ c/o Institute of Taxonomic Zoology, University of Amsterdam, The Netherlands
}

\begin{abstract}
A redescription of Gammarus fossarum Koch, 1835, is given, together with some notes on the variability in morpho'ogical characters of this species, both within one population and in different populations. It is proved through crosses that five morphologically different populations all belong to the same species, $G$. fossarum. The geographic variation of the various characters is discussed.
\end{abstract}

\section{INTRODUCTION}

Gammarus fossarum Koch, 1835, has been a source of confusion during a long time, since it was alternately considered a true species (Schellenberg, 1934) or a subspecies of Gammarus pulex (see Schellenberg, 1937). Wautier \& Roux (1959) and Roux (1967) tried to clear its systematical position through experimental interbreeding of $G$. fossarum and G. pulex; since no juveniles could be obtained, both forms are to be considered good species.

The problem was not completely solved, however, by these experiments, because Wautier \& Roux used populations of $G$. fossarum from the French Alps, the morphological characters of which are very different from those from other parts of Western Europe, as will be shown in the sequel.

Of course the problem of the morphological variability it not new, and is reflected by the several different names that were given to certain "varieties" of this species (viz. Gammarus delebecquei Chevreux \& De Guerne, 1892; Rivulogammarus pulex danubialis Karaman, 1931; and Rivulogammarus pulex rambouseki Karaman, 1931).

Therefore it was thought wise to make a study of the various morphologically different populations from Western Europe.
Material from Poland, which Jazdzewski, 1970, considered to be G. wautieri Roux, 1967, should be regarded in our opinion as one of the many varieties of $G$. fossarum.

In addition we thought it to be of great use to run cross-breeding experiments between members of different populations, in order to understand the systematic position of various populations, being so different in morphology.

But first, we had to know what the real G. fossarum, as described by Koch, 1835, looked like; attempts to retrace the type-material of Koch failed, however. Therefore it was necessary, for the stability of nomenclature, to select a neotype, from material originating from the type locality.

Moreover, it was investigated whether correlations could be found between the geographical position and the variation pattern of certain characters.

\section{ACKNOWLEDGEMENTS}

The author is indebted to Miss M. J. van Maren, Mr. F. van der Beld, Mr. H. J. Girisch, and Mr. W. Petersen, all B.Sc. students at the University of Amsterdam, for collecting animals used in the interbreeding experiments; to Mr. R. Dijkema and Mr. K. Schirl, likewise B.Sc. students at the University of Amsterdam, for collecting animals at the type-locality; to Mr. H. H. Mittelberg of the Institute of Taxonomic Zoology, Amsterdam (I.T.Z.) for his technical assistance during the experiments; to Dr. K. Jazdzewski, of the University of Lodz, for providing material from Poland; to Prof. Dr. A. L. Roux, of the University of Lyon, for his assistance in the field work and his technical advises; to Professor Dr. J. H. Stock, of the I.T.Z., for collecting material and his critical remarks during all phases of the work.

Special thanks are due to Mr. S. Pinkster, M.Sc., of the I.T.Z., without whose help, both in the field and in the laboratory, this work would have never been done.

The field work was made possible through financial support of the University of Amsterdam. 

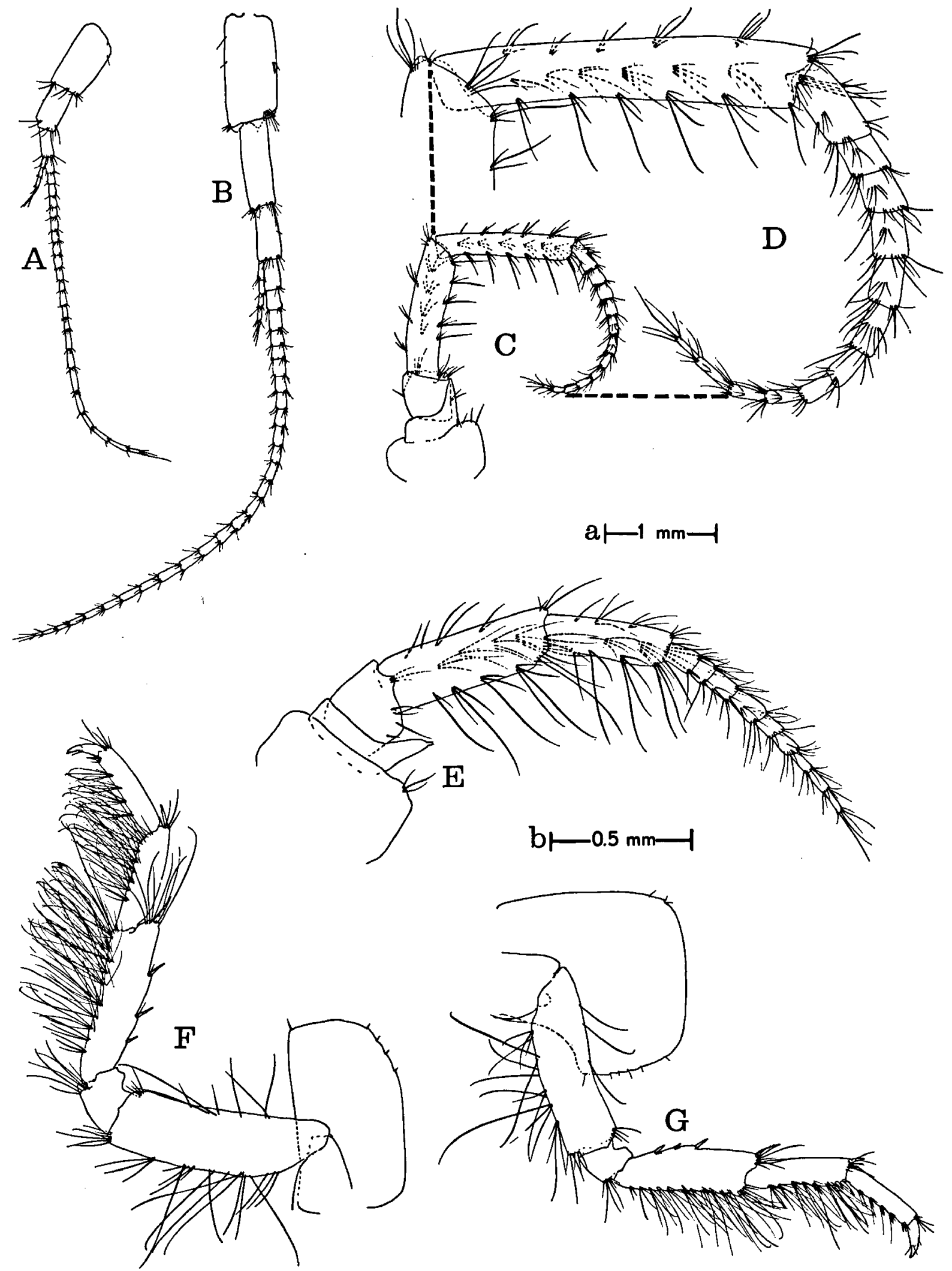

Fig. 1. Gammarus fossarum Koch, 1835, topotypes. A, E, second antenna, \& (b); F, third leg, of (a); G, fourth first antenna, + (scale a); B, first antenna, $\delta$ (a); C, second antenna, $\hat{o}$ (a); $D$, detail of same antenna (b);

E, second ant
leg, of (a). 


\section{Gammarus fossarum Koch, 1835}

Gammarus fossarum Koch, 1835: 2; Schellenberg, 1934: 214, figs. 1c, $3 b$.

Syn.: Gammarus delebecquei Chevreux \& De Guerne, 1892: 136, figs. $1,3,5$.

Rivulogammarus pulex danubialis Karaman, 1931: 102. Rivulogammarus pulex rambouseki Karaman, 1931: 103. Gammarus (Rivulogammarus) pulex fossarum; Schellenberg, 1937: 276.

non: Gammarus fossarum bodanicus Schellenberg, 1934: 216.

Material. - Many specimens, including precopulae and ovigerous females, from a little stream near the Weichselmühle, South of Regensburg a.d. Donau, Land Bayern, German Federal Republic, 25 september 1971. The $\hat{o}$ neotype, and many other specimens have been deposited in the collection of the Institute of Taxonomic Zoology (Zoölogisch Museum) Amsterdam, cat. no. Z.M.A. Amph. 103.337.

\section{DESCRIPTION OF TOPOTYPIC MATERIAL}

A rather small species: the largest male out of a sample of about 100 specimens is $14 \mathrm{~mm}$ long. The habitus is less robust than that of G.pulex (fig. 2D); the colour of live specimens is usually a lighter or darker shade of brown.

Male: The eyes are almost rounded, always less than twice as long as wide.

The first antenna (fig. 1B) is almost half the total body length of the animal, the peduncle segments resemble those of $G$. pulex: segment 2 is about as long as segment 1 and about twice as long as segment 3 . The accessory flagellum usually has 4 segments; the main flagellum has 25 to 32 segments.

The second antenna (figs. $1 C$ and D) is shorter than the first. The gland cone is rather long, pointed; it nearly reaches the distal end of peduncle segment 3 , which is about as long as wide. Peduncle segments 4 and 5 are almost equal in length, both provided with tufts of setae, implanted in 3 longitudinal rows; the setae in the inferior row have about the same length as the diameter of each of the segments 4 or 5 ; the setae in the other two rows are shorter. The flagellum has slightly flattened segments, with setae both on the inner and outer margin of the segments. In few cases calceoli can be found on the outer margin of the proximal segments.

The mandible palp (fig. 3F) has an unarmed first segment; the inferior margin of the third segment is armed with a regular comb-like row of spinules and some terminal setae. One or two lateral groups of setae can be found on both its inner and outer surface. The remaining mouth parts of this species do not show obvious differences from other species within the family Gammaridae.

The hand of the first gnathopod (fig. 2C) resembles that of $G$. pulex but is more elongate; it carries a strong medial palmar spine that is separated from the strong angle spine by a wide gap. Several small spines are implanted along the posterior margin of the hand and along the inner surface next to it. The merus and carpus of the first gnathopod (fig. 2A) bear, often curved, setae.

The hand of the second gnathopod (fig. 2G) is quadrangular and oblong, having a strong medial palmar spine and a variable number of palmar angle spines, together with some smaller ones. The hand is covered with rows of often curved setae. The merus en carpus of this leg (fig. 2E) have longer setae than those of the first gnathopod.

The last three segments of the third leg (fig. 1F) bear groups of long, curved setae along their posterior margin, in the propodus accompanied by a small spine. The number of spines along the anterior margin of the merus is variable.

The fourth leg (fig. 1G) closely resembles the third one, although the number and length of the setae is reduced.

The antero-inferior and postero-inferior corners of the first to fourth coxal plates are rounded.

The basal segments of legs 5, 6, and 7 (figs. $3 \mathrm{~A}, \mathrm{~B}, \mathrm{C})$ gradually change from slightly quadrangular in P5 to elongate in P7. The distal end of the basal segment of these legs is always wider than the proximal end of the ischium, forming a protruding lobe, always set with a small spine in leg 7. Legs 5, 6, and 7 are very slender and are usually armed with a varying number of spines or groups of spines, sometimes intermixed with a few short setae.

In adult specimens, the inner ramus of the third uropod (fig. 3D) is about half as long as the outer ramus. A varying number of setae on the inner margin of both endopod and exopod are plumose. However, very old specimens only, sometimes bear some plumose setae on the outer margin of the exopod (Meijering, 1972). The number of spines, implanted along the margins is largely variable.

The telson (fig. $3 \mathrm{H}$ ) is a little longer than the pedunculus of the third uropod. Its other features 
are as variable as in G. pulex (cf. Pinkster, 1970).

The urosome segments (fig. 2D) show neither excavations nor elevations. The armature of each segment consists of a mid-dorsal group of spines, with one or more groups of spines on each side. The number of these spines is largely variable. Each group of spines is accompanied by one or more setules, which are almost equal in length to the spines.

The postero-inferior corner of the first epimeral plate (fig. 2D) is always rounded, and is set with some short setules. The corners of the second and third plates are slightly pointed. The first epimeral plate is armed with some long setae along its anterior border. All the plates have short setules along their posterior borders. The lower margin of the last two plates is set with a few spinules.

Female: Smaller than the male, as in most other species within the family Gammaridae. The sexual dimorphism in this species resembles that of $G$. pulex (see Pinkster, 1970). The most important differences from the male sex are found in the longer setation of the peduncle of the second antenna (fig. 1E); in the smaller size of the hands of $\mathrm{P} 1$ and $\mathrm{P} 2$ (figs. 2B and F) - moreover the female has no medial palmar spine; in the smaller size of the third uropod (fig. 3E) and telson (fig. $3 G)$.

\section{Variability. -}

Within the population of $G$. fossarum from the type-locality the following characters are stable, within a certain range (depending on age and sex):

(1) the shape of the eyes;

(2) the structure of the mandible palp;

(3) the setation of the second antenna;

(4) the shape of the hands in gnathopods 1 and 2;

(5) the setation of legs 3 and 4 and of the rami of Ur3;

(6) the presence of a small spine on the protuding lobe of the basal segment of P7;

(7) the absence of plumose setae on the outer margin of the exopod of Ur3 (except in very old specimens);

(8) the length of the endopod compared with the first segment of the exopod of Ur3 (the ratio is $1: 2$ ).

Variable characters are:

(1) the number of segments in the flagellum of $\mathrm{A} 1$ and A2;
(2) the shape and setation of the epimeral plates;

(3) the armature of the telson;

(4) the number of spines on the urosome, the legs, and the rami of the third uropod.

\section{DESCRIPTION OF OTHER POPULATIONS}

During the investigation it became clear that some of the characters which were found stable in the type-locality, were largely variable in other populations: so, the setation of $\mathrm{A} 2, \mathrm{Ur} 3, \mathrm{P} 3$, and P4 can be very different from that in the "true" G. fossarum.

(I) Population from the river Slack, a small stream near Ambleteuse,* dépt. Pas-de-Calais, France (collected 25 April 1971): A2 shows the same setation as the population from Regensburg, but most of the specimens have calceoli on the flagellum (fig. 4A); the setation of P3 and P4 (figs. 5A and B) is rather short and not very abundant; Ur3 (fig. 4F) although relatively short, has a rich setation on both endo- and exopod.

(II) Population from a little stream in the spring forest at Terziet, prov. Limburg, The Netherlands (collected 3 July 1971): the flagellum of A2 (fig. 4B) is not flattened and only sometimes bears calceoli, the setae on segments 4 and 5 of the peduncle are shorter than the distance between the tufts in which they are implanted; the setation on P3 and P4 (figs. 5C and D) is short; the setation of $\mathrm{Ur} 3$ is rather poorly developed, especially in the basal portion of the exopod (fig. 4G).

(III) Population from a mountain stream near Sarcenas, $12 \mathrm{~km} \mathrm{~N}$. of Grenoble, dépt. Isère, France (collected 23 July 1971): the flagellum looks rather like that of the population from Terziet, but never bears calceoli (fig. 4C), the setae on segments 4 and 5 of the peduncle are more abundant and always longer than the diameter of the segments; P3 and P4 (figs. 5E and F) have a short setation; Ur3 (fig. $4 \mathrm{H}$ ) is rather bald, like in the population from Terziet.

(IV) Population from the Wolpertsbach near Karlsruhe, Land Baden-Württemberg, German Federal Republic (collected 6 May 1971): the flagellum of A2 (fig. 4D) is some-

*) The populations printed in italics, have been used in the interbreeding experiments. 

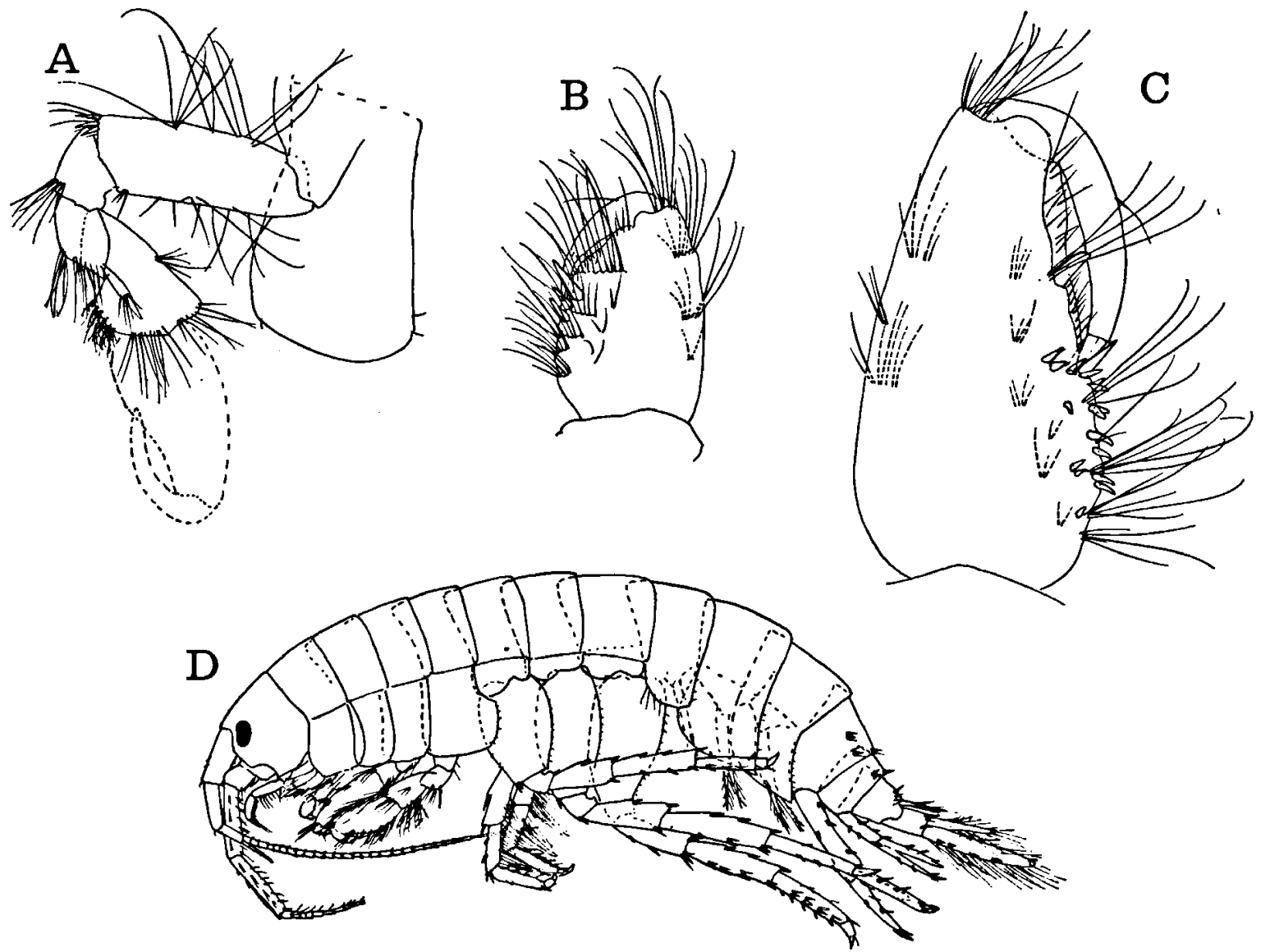

$C \longmapsto-5 \mathrm{~mm}$

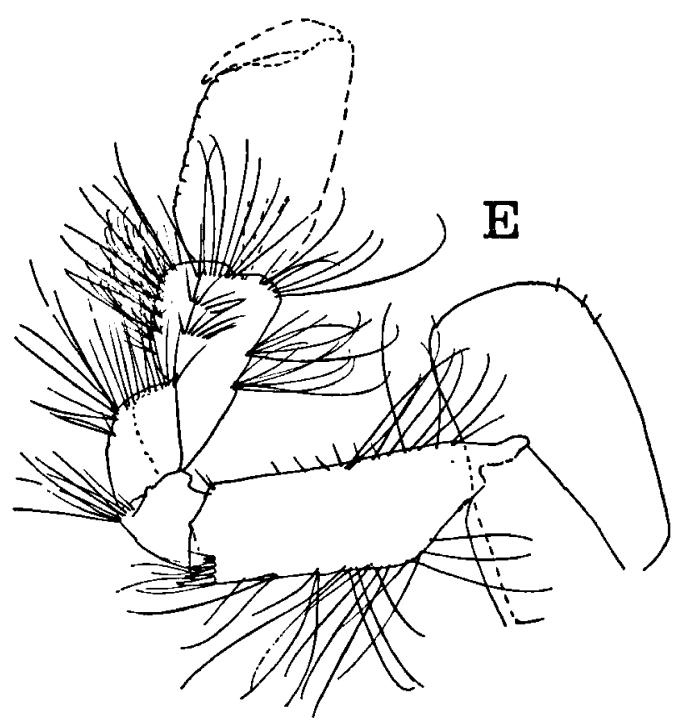

Fig. 2. Gammarus fossarum Koch, 1835, from the typelocality. A, first leg (scale a); B, hand of first leg (b); C, same, of other specimen (b); D, habitus (c); E, second
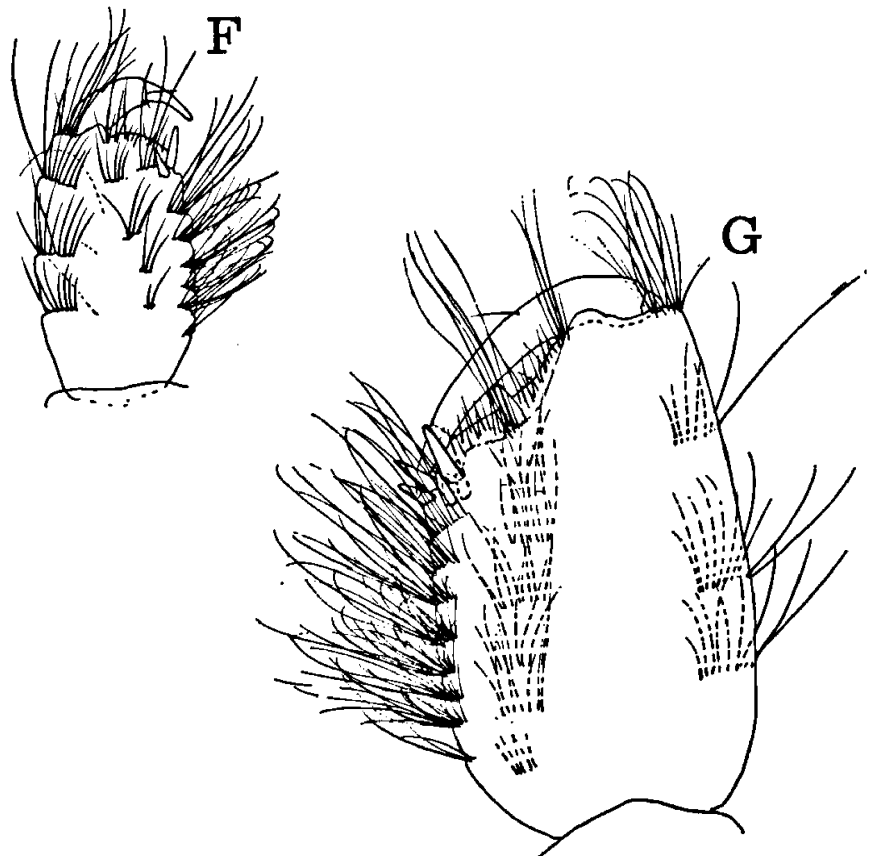

leg (a); F, hand of second leg (b); G, same of other specimen (b) [B and $F$ after $\$$, the remaining figures after $\hat{o}]$. 

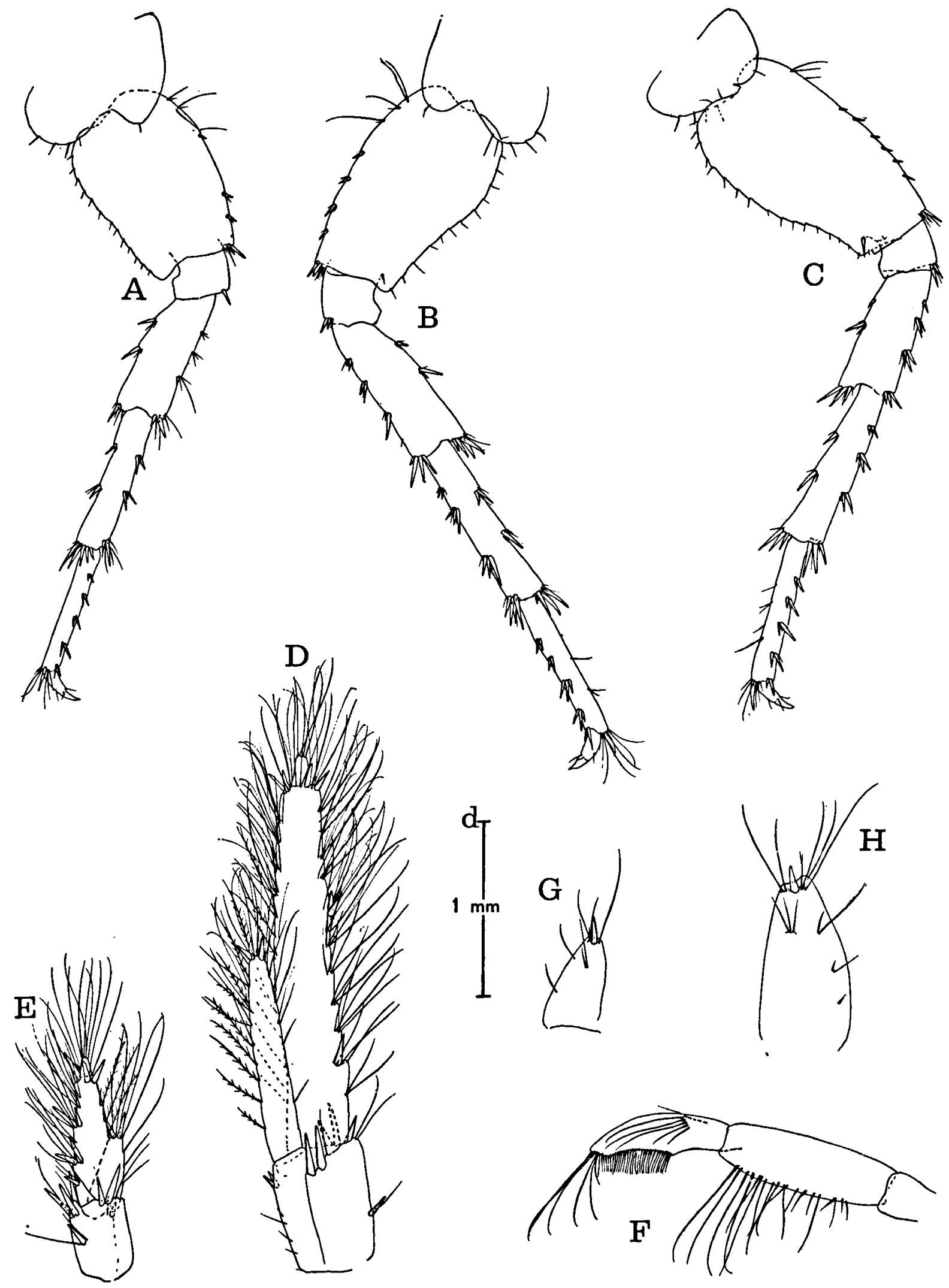

Fig. 3. Gammarus fossarum Koch 1835, from the typelocality. A, fifth leg (scale a); B, sixth leg (a); C, seventh leg (a); D, third uropod (d); E, same, of other specimen

(d); F, mandible palp (b); G, telson (b); H, same, of other specimen $[E$ and $G$ after $\&$, the remaining figures after $\delta$ ]. 


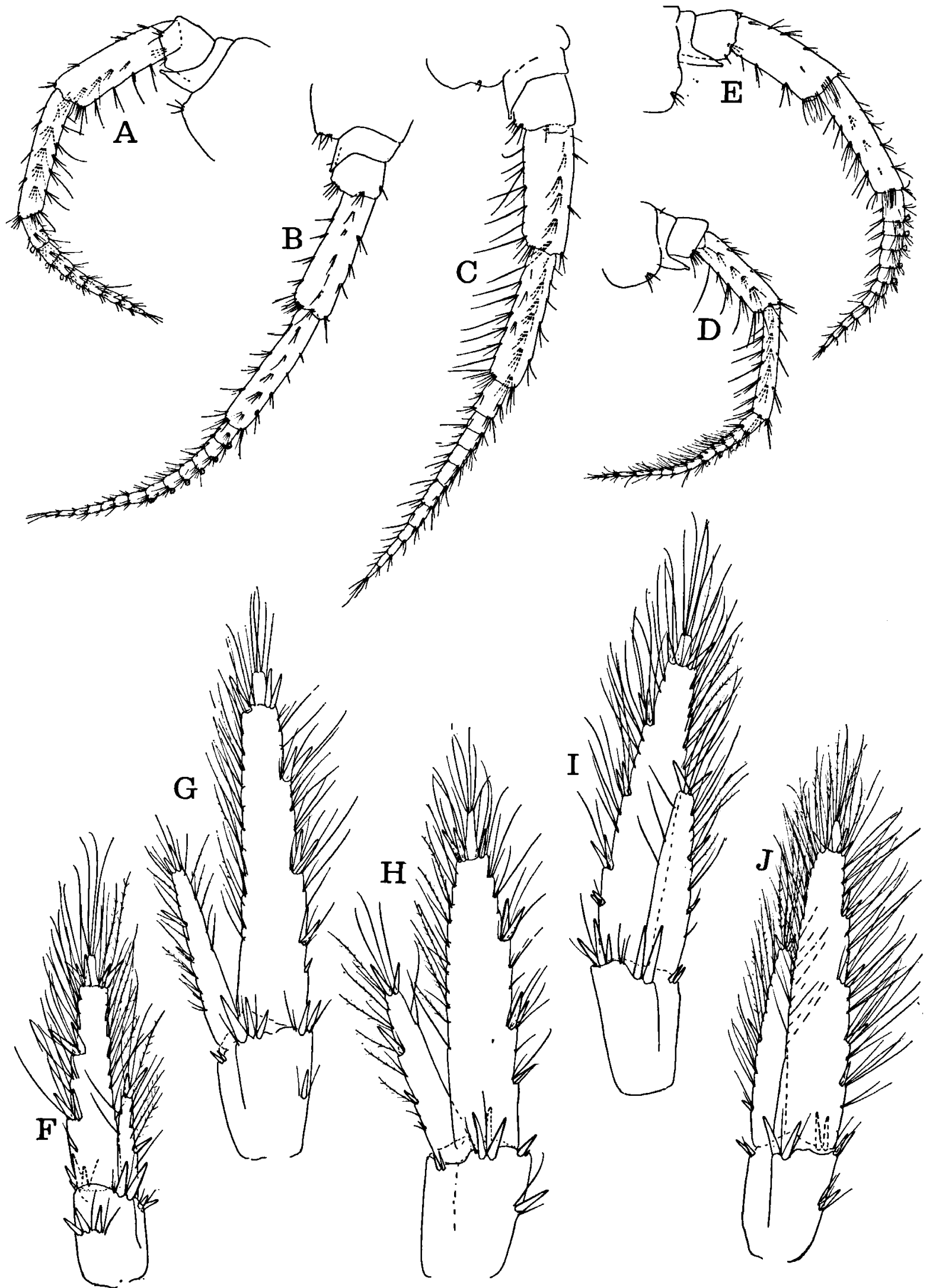

Fig. 4. Gammarus fossarum Koch, 1835, ̂. A, second antenna from Ambleteuse (France, Pas-de-Calais) (scale a); B, second antenna from Terziet (Netherlands, Limburg) (a); C, second antenna from Sarcenas (France, Isère) (a); $D$, second antenna from Karlsruhe (G.F.R., Baden-Württemberg) (a); E, second antenna from the
Grabia (Poland, Lask) (a); F, third uropod from Ambleteuse (France, Pas-de-Calais) (d); G, third uropod from Terziet (Netherlands, Limburg) (d); $\mathbf{H}$, third uropod from

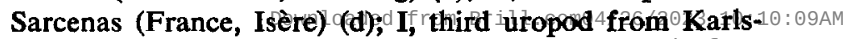
ruhe (G.F.R., Baden-Württemberg) (d); J, third uropod access from the Grabia (Poland, Lask) (d). 

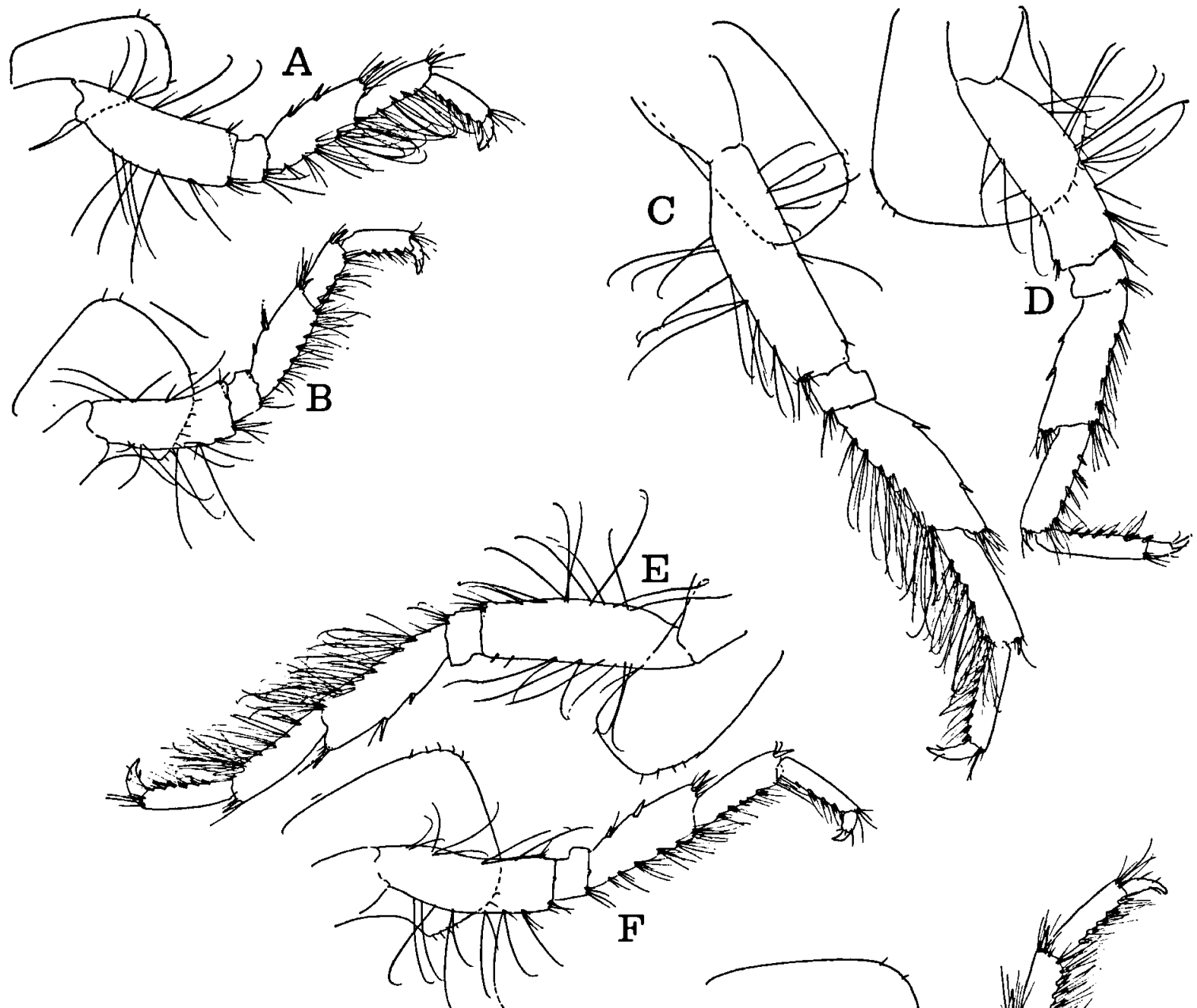

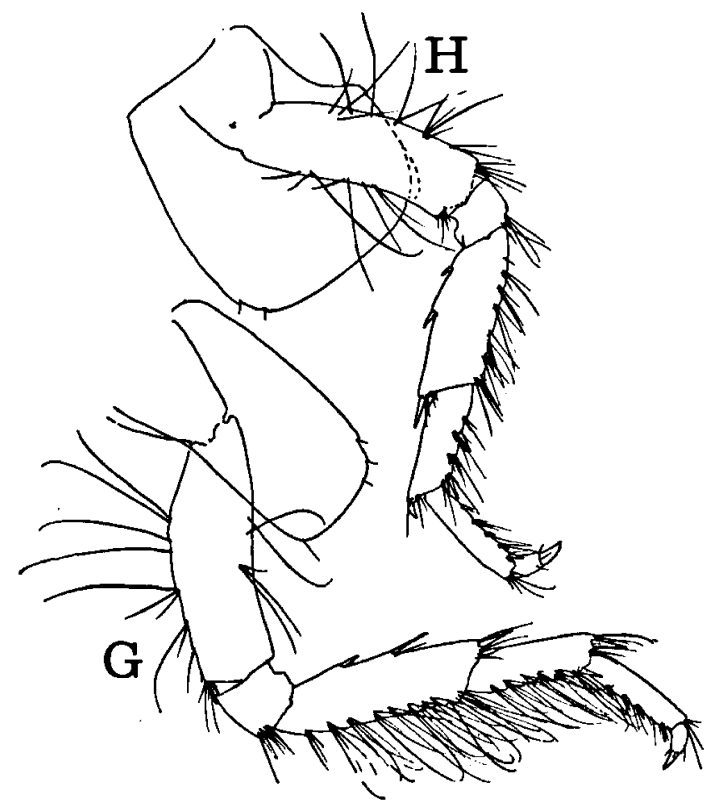

Fig. 5. Gammarus fossarum Koch, 1835, $\hat{\delta} . A$ and $B$, third and fourth leg from Ambleteuse (France, Pas-deCalais) (scale a); C and D, third and fourth leg from Terziet (Netherlands, Limburg) (a); E and F, third and fourth leg from Sarcenas (France, Isère) (a); $G$ and $H$, third and fourth leg from Karlsruhe (G.F.R., BadenWürttemberg) (a); I and J, third and fourth leg from the Grabia (Poland, Lask)(a)oaded from Brill.com04/26/2023 10:10:09AM 


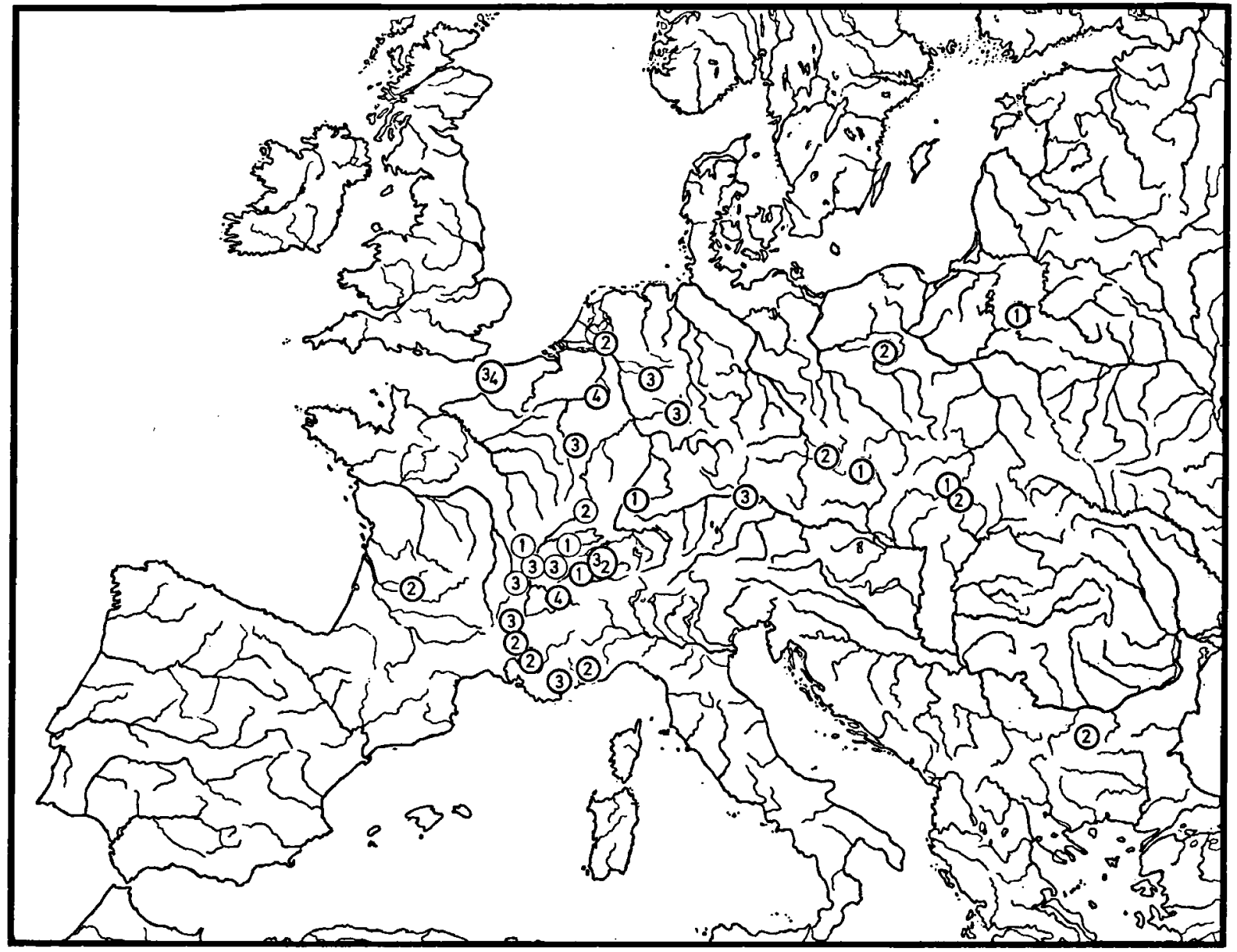

Map 1. Variability pattern of the flagellum of the second antenna in the male of G. fossarum Koch, 1835. For the

what flattened, with long setae implanted like in a brush, looking somewhat like that of $G$. pulex but not so salient; sometimes calceoli are present; the setation of the peduncle segments resembles that encountered in the population from Sarcenas; P3 and P4 (figs. 5G and $\mathrm{H}$ ) show a short setation; the armature of Ur3 is intermediate between that of the type-locality population and the population from Terziet (fig. 4I).

(V) Population from the river Grabia, a tributary of the river Warta, distr. Lask, Poland (collected by K. Jazdzewski, 17 April 1969): the flagellum of $\mathrm{A} 2$ (fig. $4 \mathrm{E}$ ) is rather flattened with short brush-like rows of setae, sometimes with calceoli; the setae on the peduncle segments are shorter than the diameter of these segments; the setation of P3 and P4 (figs. 5I and J) is slightly shorter than in the meaning of the arbitrary morphological classes 1 to 4 , see text, page 136 .

population from Regensburg; Ur3 (fig. 5J) is abundantly setose.

The same range of variation shown by the population from the type-locality is also present in other populations.

\section{DISTRIBUTION AND ECOLOGY}

G. fossarum is a widely distributed species, that has been found in southern and central Germany, France, Yugoslavia, Austria, northern Italy, Switzerland, eastern Belgium, Luxembourg, the southeastern part of the Netherlands, Roumania, Poland, northern Greece, Hungaria, Czechoslovakia and Bulgaria (see Schellenberg, 1942; Pacaud, 1952; Pljakić, 1952; Stephensen \& Hynes, 1953; Carausu, Dobreanu \& Manolache, 1955; Dusaugey, 1955; Micherdzinski, 1959; Straškraba, 1962; Hoffman, 1962; Nijssen, 1963; and material pres- 


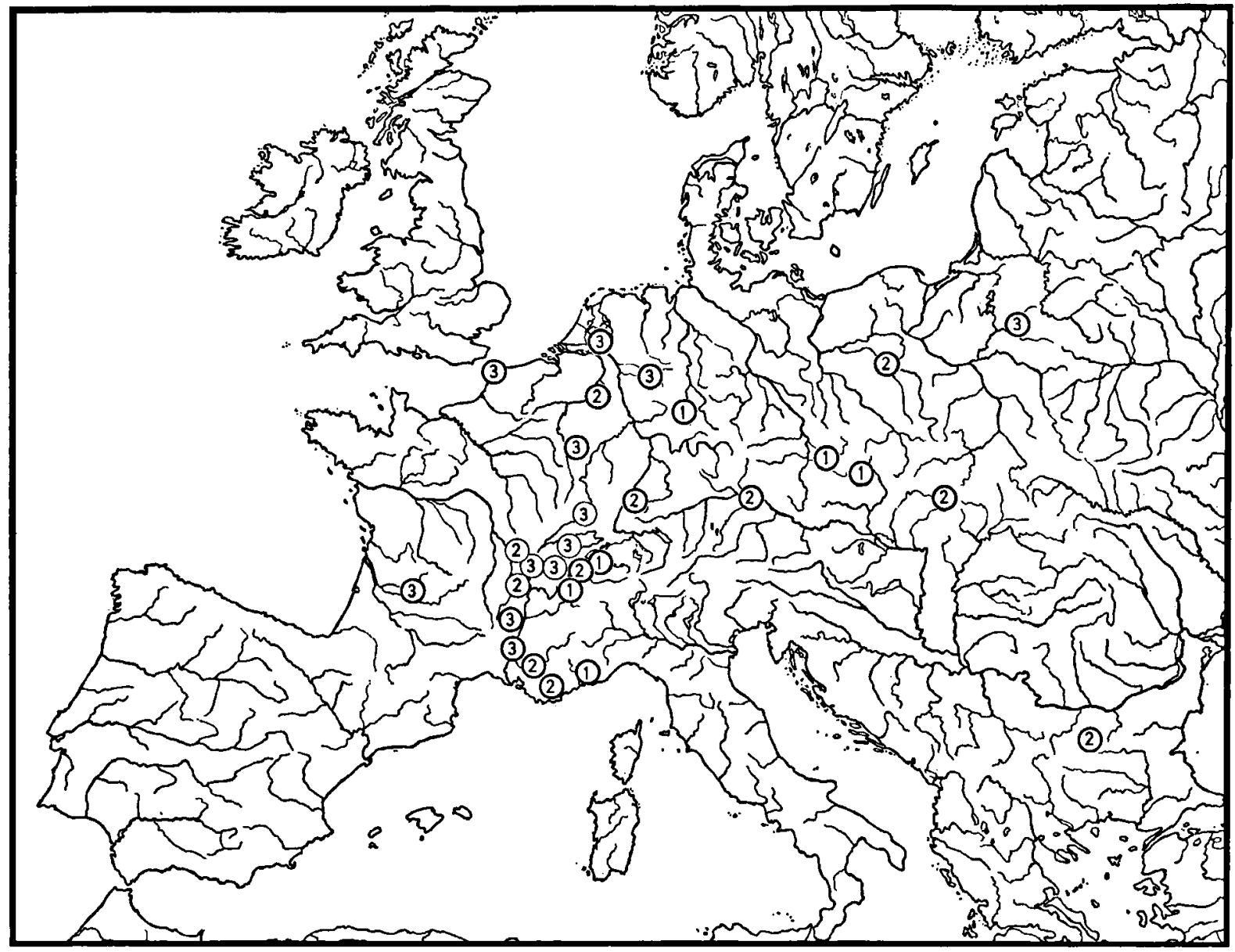

Map 2. Variability pattern of the calceoli on the flagellum of the second antenna in the male of G. fossarum Koch,
1835. For the meaning of the arbitrary morphological classes 1 to 3 , see text, page 137 .

tieri or G.pulex, it usually lives in a different microhabitat than the other two species: the fast running parts of the river bed for fossarum versus the calmer parts for the other species. This was shown by Roux (1967) for a small river in the French Alps.

In the western parts of France, where G. fossarum is absent, this type of biotope is occupied by other species, e.g. G. duebeni celticus (see Pinkster et al., 1970). The absence of $G$. fossarum from that area can be explained by the theory of Pljakic (1952), the G. fossarum is a species originating from central and south-eastern Europe that has not yet reached the westernmost part of the continent. It is a species that lives predominantly in fresh water, but like Stock, Nijssen \& Kant (1966) showed for a population at the beach of the French Channel coast, it can thrive quite well in waters with higher salinities, on condition that 


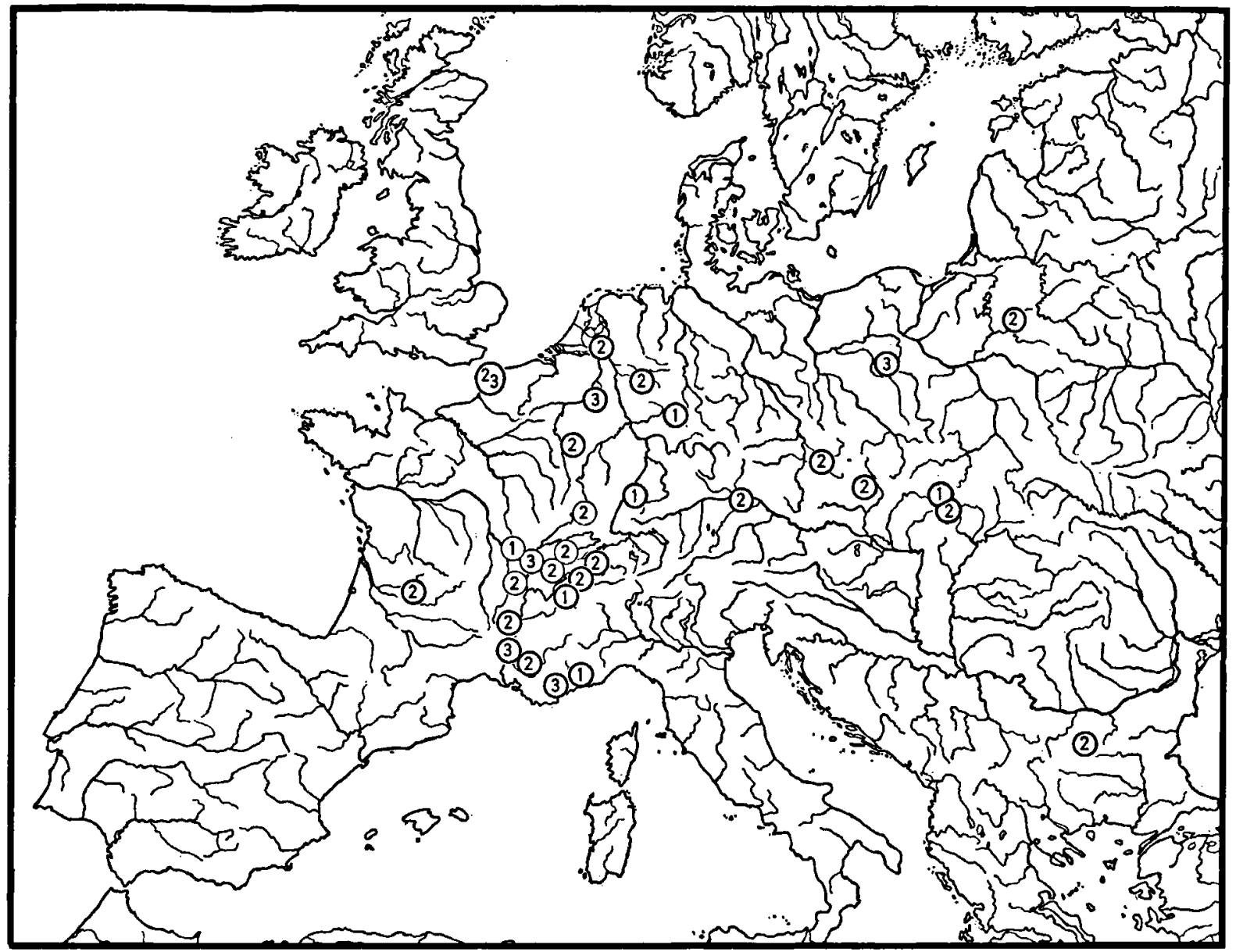

Map 3. Variability pattern of the setae along the inferior margin of the peduncle segments 4 and 5 of the second

competing species are absent.

$G$. fossarum can stand a certain degree of pollution, but it is certainly more susceptible to it than are G. pulex and G. roeseli. At increasing pollution it can be replaced by $G$. roeseli (see Besch, 1968) or other species.

Although its reproductive cycle is variable in its distribution area, it usually can produce offspring throughout the year. This can easily be explained by the rather stable conditions, especially as far as temperature is concerned, in the upstream reaches of the streams inhabited by this species.

\section{CROSS-BREEDING EXPERIMENTS}

It will be clear from the descriptive part, that important morphological differences exist between various populations identified as $G$. fossarum. In antenna of the male of G. fossarum Koch, 1835. For the meaning of the arbitrary morphological classes 1 to 3, see text, page 137 .

order to check the significance of these differences for the systematic position of these populations, hybridization experiments were started. Populations from Ambleteuse, Karlsruhe, Terziet, and Sarcenas (see descriptive part) were used.

Methods. - Samples from the populations mentioned above were kept for a week in the water in which they were found, and then slowly adapted to Amsterdam tap-water.

They were kept in storage basins of $25 \times 25 \times 10$ $\mathrm{cm}$ at a water depth of $7 \mathrm{~cm}$; the maximum number of animals per basin was 250. For hiding place a rough stone was provided; a small stream of air bubbles was constantly blown through the water; during all the experiments the temperature was kept at $15^{\circ} \mathrm{C}\left( \pm 0.5^{\circ}\right)$, and a light period of 16 hours was alternated with a dark period of 


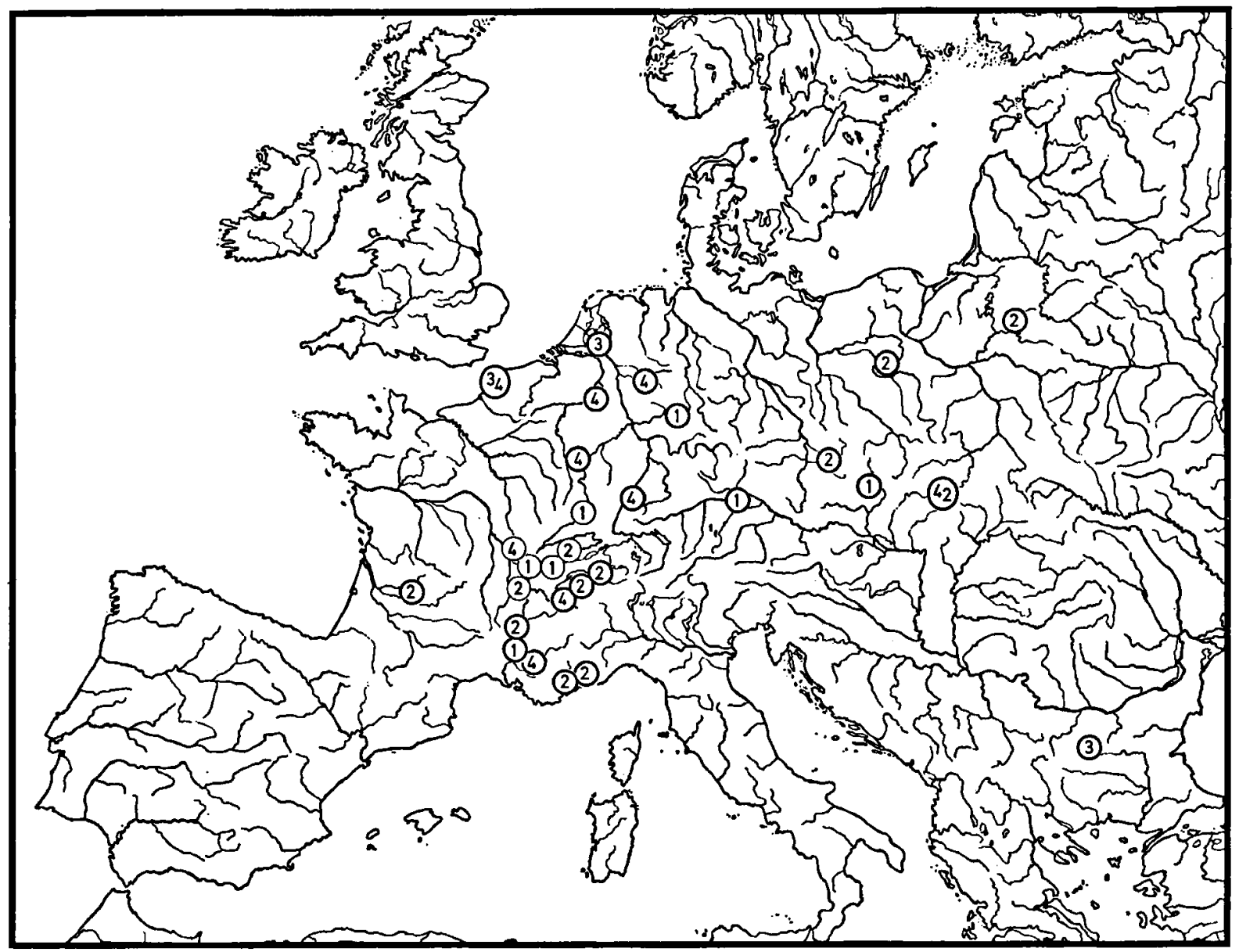

Map 4. Combined variability pattern of the setae on the third and fourth leg of the male of G. fossarum Koch,

8 hours. The animals were fed with Stellaria media Vill., a terrestrial weed that is easily available in all seasons.

For the experiments couples of animals, that swam around in precopulation, were taken out of the storage basins and separated by taking them on the hand, and afterwards put into separate basins. By this procedure one can be sure that all animals used are sexually mature, and ready to go into precopulation. Ovigerous females were kept apart until they lost their eggs. Females without eggs could be used immediately for the experiments.

In the experiments a certain number of females was put together with the same number of males, from the same or from another population. Every second day, the number of precopulations was counted; every female, that turned ovigerous in the experimentation basins was placed in a sepa-
1835. For the meaning of the arbitrary morphological classes 1 to 4 , see text, page 137.

rate basin of $7 \times 7 \times 10 \mathrm{~cm}$, water depth $7 \mathrm{~cm}$, under aeration. A small stone was always added.

In later experiments some 10 to 40 ovigerous females were put together in the larger basins and only set apart at the moment, that their eggs turned orange, a sign that the juveniles could be expected in two or three days. Every day the ovigerous females were checked, if they were still alive and possessed eggs. As soon as a female produced an offspring, it was taken out of the small basin, in order to prevent the juveniles from being eaten by the mother.

It was not always easy to raise the young mainly because of lack of time and space to attend properly to them.

The results of the various crosses are summarized in table $\mathbf{I}$.

In experiments $A, B$, and $I$ every ovigerous female was kept apart during the whole period of 
development of the eggs; in the other experiments ovigerous females were kept together until a few days before the hatching of the eggs.

When we compare the results of experiments I, $\mathrm{J}$, and $\mathrm{K}$, we must come to the conclusion, that the different way of treating the ovigerous females has no direct influence on the success of the crosses. The diversity observed in the results between $I$ and $K$ is most probably caused by the differences in season, and by the period that the animals had already spent in the laboratory; in experiment $\mathrm{J}$, the animals had lived for more than two months under laboratory conditions, before they were used in the experiments.

To make sure that no parthenogenesis could have taken place, 50 "empty" females originating from precopulations from Ambleteuse were isolated. Within one week $50 \%$ produced eggs: these eggs, however, never developed beyond a certain stage and were removed by the female usually within 5 days.

The results of the crosses show, that all tested populations of $G$. fossarum are interfertile; the differences in fertility can be explained by the way in which the females, used in the various experiments, can stand laboratory conditions. The populations from Ambleteuse and Karlsruhe are apparently more able to thrive under laboratory conditions, than their relatives from Terziet and Sarcenas.
Moreover, we must realize, that the reproductive cycles in the various populations do not necessarily correspond to each other.

\section{GEOGRAPHICAL VARIATION}

In order to verify if a relation exists between some of the main characters (discussed in the descriptive part) and the geographic distribution, the morphological "varieties" were plotted on maps.

On separate maps, each of the following features has been plotted:

(a) the degree of compression and setation of the flagellum of A2 of (see map 1);

(b) the presence or absence of calceoli on the flagellum of A2 of (see map 2);

(c) the length of the setae on peduncle segments 4 and 5 of A2 of (see map 3);

(d) the setation of P3 and P4 \& (see map 4);

(e) the setation of Ur3 $f$ (see map 5).

For each of features (a) through (e), a subdivision into arbitrary classes is proposed, as follows:
(a) - flagellum compressed
setae longer than the diameter of the flagellar segments
setae as long as, or shorter
- flagellum
not compressed $\left\{\begin{array}{l}\text { setae as long as the diameter } \\ \text { of the flagellar segments } \\ \text { class } 3 \\ \text { setae shorter than these } \\ \text { segments } . . . \text {. class } 4\end{array}\right.$

Table I. Gammarus fossarum: results of inter-populational (heterogeneous) and intra-populational (homogeneous) crosses.

\begin{tabular}{|c|c|c|c|c|c|c|c|}
\hline \multicolumn{8}{|c|}{ Couples of heterogeneous origin. } \\
\hline code & $\begin{array}{c}\text { number of } \\
\text { pairs }\end{array}$ & $\$ \%$ & ồ & ov. 9 \% & $q$ with juv. & \%ov. 우 9 & $\%$ \% with juv. \\
\hline $\mathbf{A}$ & 19 & Ambleteuse $1^{1}$ ) & Karlsruhe & 19 & 6 & 100 & 32 \\
\hline B & 22 & Karlsruhe & Ambleteuse 1 & 20 & 7 & 91 & 32 \\
\hline C & 100 & Ambleteuse $2^{2}$ ) & Terziet & 89 & 74 & 89 & 74 \\
\hline D & 100 & Terziet & Ambleteuse 2 & 33 & 18 & 33 & 18 \\
\hline $\mathbf{E}$ & 56 & Ambleteuse 2 & Sarcenas & 53 & 32 & 95 & 52 \\
\hline $\mathbf{F}$ & 50 & Sarcenas & Ambleteuse 2 & 24 & 8 & 48 & 16 \\
\hline G & 62 & Terziet & Sarcenas & 29 & 14 & 47 & 23 \\
\hline $\mathbf{H}$ & 50 & Sarcenas & Terziet & 28 & 6 & 56 & 12 \\
\hline
\end{tabular}

Couples of homogeneous origin.

$\begin{array}{llllllll}\text { I } & 50 & \text { Ambleteuse 1 } & \text { Ambleteuse 1 } & 47 & 17 & 94 & 34 \\ \text { J } & 50 & \text { Ambleteuse 1 } & \text { Ambleteuse 1 } & 37 & 10 & 74 & 20 \\ \text { K } & 50 & \text { Ambleteuse 2 } & \text { Ambleteuse 2 } & 36 & 31 & 72 & 62 \\ \text { L } & 50 & \text { Terziet } & \text { Terziet } & 25 & 12 & 50 & 24 \\ \text { M } & 36 & \text { Sarcenas } & \text { Sarcenas } & 15 & 8 & 42 & 22\end{array}$

1) Ambleteuse 1: animals collected in April

2) Ambleteuse 2: animals collected in July 


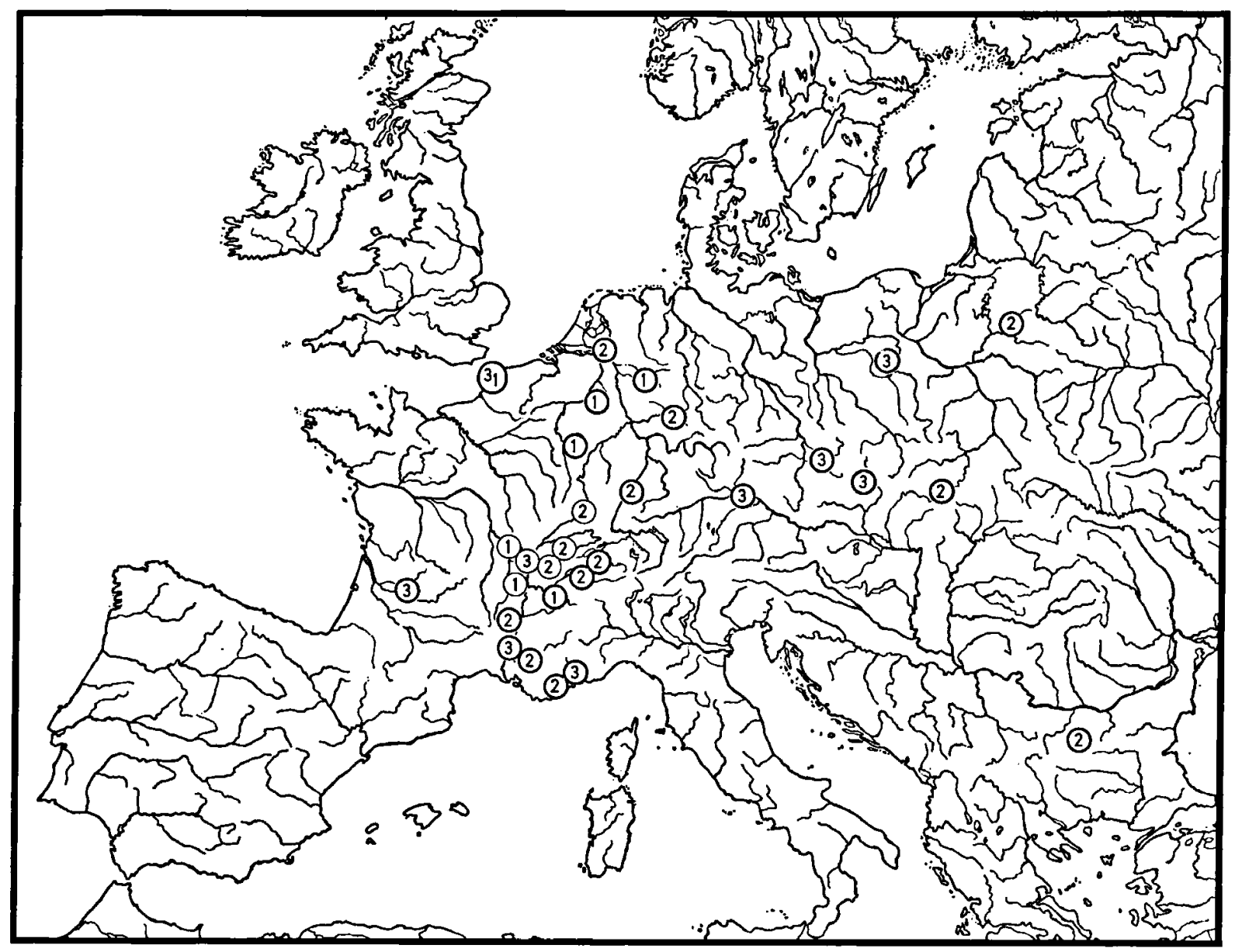

Map 5. Variability pattern of the setation of the third uropod of the male of G. fossarum Koch, 1835. For the meaning of the arbitrary morphological classes 1 to 3 , see text, page 137. (b) - calceoli always present . . . . . . class 1

— calceoli sometimes present . $. . \quad . \quad . \quad$. class 2

- calceoli always absent . . . . . . class 3

(c) - setae longer than the diameter of the segments ............ class 1

- setae as long as the diameter of the segments

class 2

- setae shorter than the diameter of the segments

class 3

(d) - abundant setation (setae on P3 and P4 longer than the diameter of the legs) . . . . . . class 1

- relatively well developed setation (setae on P3 longer than the diameter of the leg, setae on P4 as long as the diameter of the leg). . . class 2

- normally developed setation (setae on P3 and P4 as long as the diameter of the legs). . class 3

- poorly developed setation (setae on P3 as long as the diameter of the leg, setae on P4 shorter than the diameter of the leg)... . . . class 4 (e) - poor setation . . . . . . . . . . class 1 - medium setation . . . . . . . . . . class 2 - rich setation. . . . . . . . . . . class 3

Taking all evidence (the great morphological variation, the absence of reproductive isolation, the absence of any regularity in the distribution pattern of various characters, the absence of geographical isolation barriers) in consideration, we must come to the conclusion that all these morphologically different populations are mere varieties of one and the same species: $G$. fossarum.

These differences are probably morphological expressions of adaptations to different ecological conditions (ecophenotypical variations). 


\section{REFERENCES}

BESCH, W., 1968. Zur Verbreitung der Arten des Genus Rivulogammarus in Fliessgewässern Nordbadens und Südwürttembergs. Beitr. naturk. Forsch. Südw.-Dtl., $27: 27-33$.

Carauşu, S., E. Dobreanu \& C. Manolache, 1955. Faune republicii populare Romîne. Crustacea, 4 (4), Amphipoda, forme salmastre si de apa dulce: $1-407$. (Acad. Rep. Pop. Rom., Bucarest).

Chevreux, E. \& J. De Guerne, 1892. Description de Gammarus delebecquei nov. sp. du lac d'Annecy, suivie de quelques remarques sur les Amphipodes d'eau douce de la France. Bull. Soc. zool. France, 17 : $136-142$.

Dusaugey, J., 1955. Les Gammares du Dauphiné et leur répartition. Trav. Lab. hydrobiol. pisc. Univ. Grenoble, 42 : 9-18.

Hoffmann, J., 1963. Faune des Amphipodes du GrandDuché de Luxembourg. Arch. Inst. Gr.-Duc. Luxembourg, (n. S.) $29: 77-128$.

JAZDZEWSKI, K., 1970. Notatka o Skrorupiakach Rzeki Biebrzy, Zeszyty nauk. Uniw. Lódz., (2) $40: 47-55$.

Kallnbach, M. E. \& M. P. D. Meijering, 1970. Die Gammariden der Haune. Beitr. naturk. Osthessen, 2 : $51-60$.

Karaman, S., 1931. 4. Beitrag zur Kenntnis der Süsswasseramphipoden. Bull. Soc. sci. Skoplje, 9 : 93107.

КосH, C. L., 1835. Deutschlands Crustaceen, Myriapoden und Arachniden. Ein Beitrag zur Deutschen Fauna. Heft 5, no. $1: 1-24$. (G. A. W. Herrich-Schäfer, Regensburg).

Meijering, M. P. D., 1971. Die Gammarusfauna der Schlitzländer Fliessgewässer. Arch. Hydrobiol., 68 (4): 575-608.

-, 1972. Physiologische Beiträge zur Frage der systematischen Stellung von Gammarus pulex und Gammarus fossarum Koch. Crustaceana, suppl. 3: 313-325.

Micherdzinski, W. 1959. Die Gammarusarten (Amphipoda) Polens. Acta zool. Cracov., 4 (10): 527-637.

Nussen, H., 1963. Some notes on the distribution and the ecology of the amphipod Gammarus fossarum Koch, 1835, in the Netherlands (Crustacea, Malacostraca). Beaufortia, 10 (116) : 40-43.
Pacaud, A., 1952. Nouvelle revue de la distribution géografique des Gammares dans les eaux continentales françaises. C.R. Soc. biogéogr., 252-253 : 96-111.

Pinkster, S., 1970. Redescription of Gammarus pulex (Linnaeus, 1758) based on neotype material (Amphipoda). Crustaceana, $18(2): 177-186$.

Pinkster, S., A. L. Dennert, B. Stock \& J. H. Stock, 1970. The problem of European freshwater populations of Gammarus duebeni Liljeborg, 1892. Bijdr. Dierk., 40 (2) : 116-147

Pluakič, M., 1952. A contribution to the study of the distribution of Gammarus (Rivulogammarus) pulex fossarum in Serbia. Arch. biol. Sci., 1-2 : 81-88.

Roux, A. L., 1967. Les Gammares du groupe pulex (Crustacés, Amphipodes) - Essai de systématique biologique. Thèse Fac. sci. Univ. Lyon, 447 : $\mathrm{i}-$ vii, 1-172.

Schellenberg, A., 1934. Der Gammarus des Deutschen Süsswassers. Zool. Anz., 108 (9/10) : 209-217.

-, 1937. Schlüssel und Diagnosen der dem SüsswasserGammarus nahestehenden Einheiten ausschliesslich der Arten des Baikalsees und Australiens. Zool. Anz., $117(11 / 12)$ : $267-280$.

-, 1942. Krebstiere oder Crustacea, 4. Flohkrebse oder Amphipoda. Tierwelt Deutschlands, $40: 1-252$.

STEPHENSEN, K. \& H. B. N. HyNEs, 1953. Notes on some Belgian freshwater and brackish water Gammarus. Vidensk. Medd. Dansk. naturk. Foren., 115 : 289304.

Stock, J. H., H. Niussen \& P. KanT, 1966. La répartition écologique des Amphipodes de la famille des Gammaridae dans la Slack et son estuaire. Bull. zool. Mus. Univ. Amsterdam, 1 (3) : 19-30.

STRAŠKRABA, M. 1962. Amphipoden der Tschechoslowakei nach den Sammlungen von Prof. Hrabé, 1. Acta Soc. zool. Bohemoslovenicae, 26 (2) : 117-145.

-, 1967. Amphipoda. In: J. ILlIES, Limnofauna Europaea: 202-208. (Gustav Fischer Verlag, Stuttgart).

Wautier, J. \& A. L. Roux, 1959. Note sur les Gammares du groupe pulex dans la région Lyonnaise. Bull. mens. Soc. linn. Lyon, $28(3): 76-83$. 